\title{
Innovation, Music and Future Making by Young Africans in a Challenging Environment: Examples from Cameroon and Nigeria
}

\author{
Jonathan Ngeh and Michaela Pelican
}

The Africa continent has the youngest population in the world. In sub-Saharan Africa, the focus of our analysis, 62 per cent of the population is below the age of 25 (UNDESA 2019). If productively employed, a large working-age population is a potential resource for economic growth and development (Ashford 2007).

The staggeringly high rates of youth unemployment in Africa (Baah-Boateng 2016) indicate that the continent is making poor use of its youthful population. Mohamed Yahya, regional programme coordinator of UNDP Africa wrote in 2017 that Africa is "stubbornly inhospitable - politically, economically, and socially - to young people" (UNDP Africa 2017). At an event in March 2018 in Kigali, and in the presence of the Rwandan president and other African leaders, the Sudanese businessman and philanthropist Mohammed Mo Ibrahim criticized Africa's gerontocracy. "We are the only continent in the world where we have presidents at ninety years old starting new terms; I mean you guys are crazy or what? We see people in wheelchairs, unable to raise their hands standing for elections, this is a joke" (Ibrahim 2018). Ibrahim's critique resonates with African frustration with their long serving dictators and reflects a popular sentiment among those who oppose such practices. A notable example is former Botswana president Ian Khama who openly criticized several of his African peers for hanging onto power well beyond the limits of their terms (Hall 2015).

Policy proposals to solve high youth unemployment and exclusion from governance are numerous and include investment in education, training and healthcare and promoting youth-friendly policies, peace and security. To varying degrees, African states have taken concrete action to match the urgency of these proposals, mainly through creating national employment and empowerment programmes to equip high school and university graduates with the skills they need to find jobs (Zukane and Tangang 2017). Complementing the efforts of African states in this endeavour is the support of intergovernmental organizations. For example, the African Youth Charter established in 2006

(C) JONATHAN NGEH AND MICHAELA PELICAN, 2022 | DOI:10.1163/9789004471641_024

This is an open access chapter distributed under the terms of the CC BY-NC 4.0 License. 
by the African Union provides a strategic framework for youth advancement and empowerment across Africa at continental, regional and national levels (African Union 2006). The United Nations collaborates with the African Union Commission to support the capacity development of young Africans through the umbrella initiative of the UN programme Youth4South (UNOSSC 2019).

A common thread in the above initiatives is their top-down approach, which sidelines young Africans at the levels of both conception and execution. Because of this shortcoming, we view the current approach to the delineated problems affecting African youth as cosmetic and superficial, for it does little to change the status quo allowing for the concentration of economic and political power in the hands of mostly elderly African men, some of whom have been part of the ruling elite since independence. ${ }^{1}$ Our aim in this think piece is, through the example of Collins Nji, a young man from the English-speaking parts of Cameroon who won the international Google Code-in competition despite an emergent political crisis, to unlock the potential of young Africans as agents of future making and key actors in transforming their communities and the continent. We explore how African youth - confronted by challenging political and economic environments and riddled with uncertainty, lack of governmental support and gerontocracy - come up with a spirit of innovation and determination for future making. To substantiate our argument, we also draw on examples of young African artists, such as the Nigerian Afrobeats singer Wizkid, who have gone global and have placed Africa firmly on the map of global trendsetting.

The past decade has witnessed a growing rise in tech innovation and entrepreneurship across Africa, driven almost entirely by African youth. Across the continent we have seen an increase in the number of active tech hubs, which provide space in which start-up companies can grow (Bayen and Giuliani 2018). Also, we have seen the CEO s of tech giant companies visit Africa and meet young tech developers. Microsoft's Satya Nadella visited Kenya in 2015;

1 For example, the current Zimbabwean president Emmerson Mnangagwa has occupied senior cabinet positions from 1980 when Zimbabwe gained independence to the late 1980 s, then became the speaker of the parliament from 2000 to 2005 , occupied other cabinet positions after leaving parliament until 2017 when Mugabe dismissed him from the position of vice president, and a few months later, he succeeded Mugabe as president. We get a similar picture in Cameroon and other African countries where the president and many of his cabinet officials have served in various political positions since independence. 
Facebook's CEo Mark Zuckerberg visited Kenya and Nigeria in 2016; Google's CEO Sundar Pichai went to Nigeria in 2017 and later in 2018 visited Ghana; Alibaba founder Jack Ma has been to several African countries since 2017; and Twitter's founder and CEo Jack Dorsey travelled to Nigeria, Ghana and Ethiopia in 2019 (Forbes Africa 2020). Africa's tech industry is also attracting the attention of European leaders. In 2017, the French president Emmanuel Macron and Dutch prime minister Mark Rutte visited the Impact Hub in Accra (Ayitey 2017), a non-profit organization aimed at building a globally integrated entrepreneurial community to promote high impact developments in West Africa. A year later, the German chancellor Angela Merkel visited the Impact Hub in Accra.

Compared with Ghana, Kenya, South Africa, Nigeria, Morocco and Egypt, where the tech industry is fairly well established (Bayen and Giuliani 2018), Cameroon lags far behind. Yet, in 2016, Collins Nji, then a 17-year-old anglophone high school student, took part in the annual Google Code-in (GCI) competition and won a grand prize (Figure 1). This made him the first African to win the competition since its launch in 2010 (вBC Africa 2017). Most remarkable about Collins's success was that his participation in the competition coincided with the beginning of a political crisis in the English-speaking parts of Cameroon, which resulted in the closure of schools and internet interruptions. In total, 1340 students from 62 countries participated in the competition in 2016 and Collins was one of the 34 grand-prize winners from 16 countries. They were awarded a trip to Google's main headquarters in San Francisco to meet Google engineers (Radomile 2017).

Collins's achievement received international press coverage for its historic nature and for succeeding in the face of near insurmountable obstacles, caused by the political unrest in his home town. ${ }^{2}$ With only 40 computers between more than 1500 students at the government bilingual high school in Bamenda, to study coding at school Collins had to struggle to gain access both to a computer and to the internet. At home, he sought knowledge mostly from freely available online sources, which he read and applied on his father's computer. Most challenging was the final phase of the Google competition when regular internet shutdowns complicated the completion of the tasks. Impressed

2 A Google search of the name Nji Collins [Gbah], for example, will generate hundreds of hits on the story in different languages around the world. Different news articles about Collins have interchanged the order of his names, a problem caused by the fact that in Cameroon it is common to have an African name as the first name and a European first name as the second name. In our conversation with Collins he gave us the right order of his names as Collins Nji. 


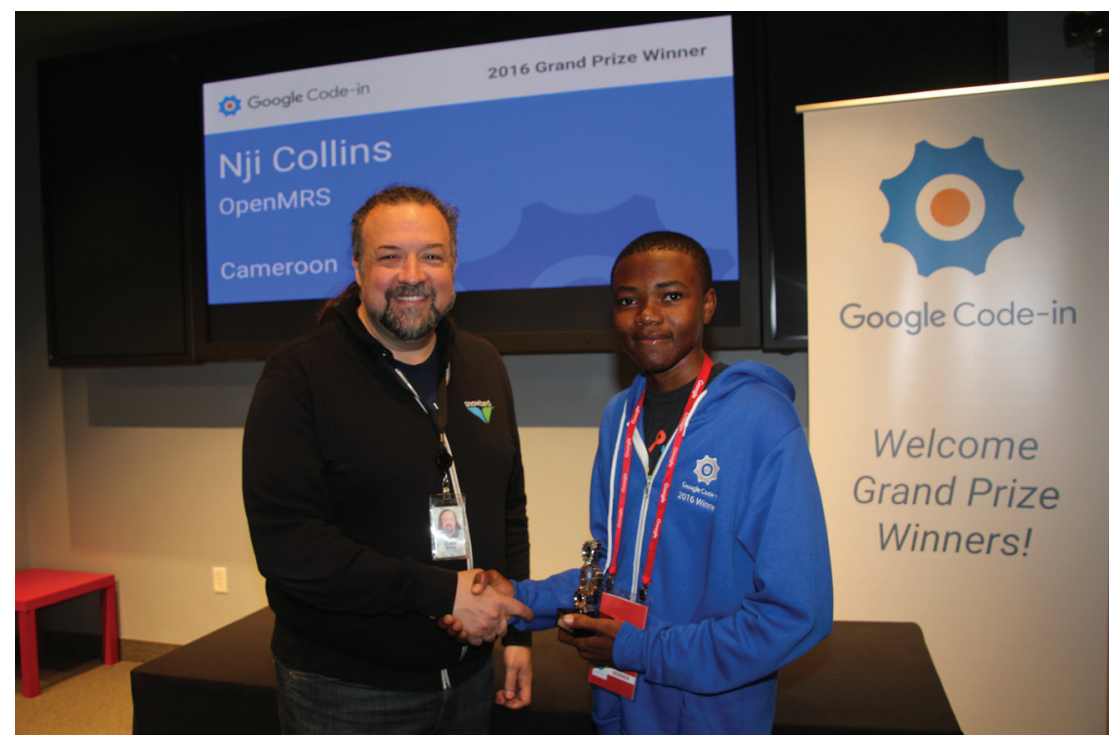

FIGURE 1 Chris DiBona, director of Open Source at Google, congratulating Collins Nji to his prize in June 2017, Silicon Valley PHOTO CREDIT: COLLINS NJI

by Collins's creativity and stamina, in a tweet Google cEo Sundar Pichai expressed his admiration and desire to meet with him in person (Pichai 2017).

Collins's success inspired other young people in his school and beyond to embrace coding. Later, in 2018, Enjeck Cleopatra, a high school student in Bamenda, won the GCI grand prize, the first young woman from Africa to do so. Unfortunately, she received less media coverage than Collins, but her success was equally impressive and even more challenging insofar as she competed and won at a time when the political situation had degenerated into active armed conflict and high levels of insecurity (Human Rights Watch 2019).

Importantly, Collins and Cleopatra were embedded in a network of young innovators in the small tech community of Silicon Mountain in Buea, about 300 kilometres from Bamenda. In 2015, the Silicon Mountain pioneers organized an outreach programme to high schools in Bamenda, where they met Collins and other young tech enthusiasts with whom they maintained contact and mentorship (Cleopatra was still in secondary school then). That the creators of Silicon Mountain, mostly in their twenties when the project began (Ngwa 2017), are responsible for building the leading tech hub in Cameroon without any support from the state, is a testament to their contribution towards attracting investment, impacting lives and driving mobile technological change in Cameroon. Their success (and that of many young Africans across the continent) indicates that Africans are not only consuming mobile technology but 
also adapting it to fit local needs and, in the process, changing it (Mavhunga 2017). Their achievement in hosting start-ups and global tech companies has gained them financial support from local and international investors, including companies and Cameroonian business people with an interest in Iт. In February 2020, the French ambassador to Cameroon visited Silicon Mountain with a delegation of French entrepreneurs. They donated two heavy duty standby generators and acknowledged the contribution of young innovators to crafting Cameroon's future. ${ }^{3}$ Unlike local and foreign investors, the Cameroonian government has largely failed either to support innovative tech enterprises like Silicon Mountain in Buea (Atabong 2019) or to recognize the young people's creative potential.

Like Silicon Mountain, tech innovators in other African countries have also pioneered profitable economic niches to attract foreign partnerships and contribute to global tech innovation, the most notable, specifically from Kenya, being M-Pesa, Ushahidi and mHealth. The mobile phone-based money transfer innovation M-Pesa provides formal financial services to the masses at very low rates (Onsongo 2019). In fact, Africa is now the world leader in mobile banking and the African inventiveness behind the initiative caught the attention of the then president of the USA, Barack Obama (King et al. 2014). Ushahidi, which is a crisis crowdsourcing platform, started as a website in the aftermath of Kenya's disputed 2007 presidential election. It collects eyewitness accounts of reported incidents by email and short message service (SMS) and places them on Google Maps (Pánek et al. 2017). Lastly, mHealth, which uses information technology to manage patient care, is already making a positive contribution to Kenya and to the rest of the continent (Hampshire et al. 2015). Several other tech innovations from Africa are transforming different sectors of the local economy, promoting efficiency and creating economic opportunities (Mavhunga 2017). The most notable are multimedia platforms for music sharing, for example Simfy Africa (South Africa), Spinlet and Las Gidi Tunes (Nigeria), and Mziiki (Tanzania). They have opened up possibilities for African artists to reach new audiences and benefit financially from their music streaming services of the platforms (Mavhunga 2017). This development has no doubt contributed to the growth of African music, another economic niche on the continent dominated by young Africans. We now turn to our second case, young African artists who have emerged as new global trendsetters.

3 The original tweet by the French ambassador Christophe Guilhou (21 February 2020) reads: "Le future du \#Cameroun passe par l'innovation et la France est au rendez-vous. Bravo et merci!" (see also Nadesh 2020). 


\section{$3 \quad$ Shaping and Exporting African Popular Culture}

The last decade has witnessed the rise of Afrobeats as arguably the fastest growing cultural export from Africa. "Not to be confused with Afrobeat - a genre fusing traditional Yoruba music with jazz, West African highlife and funk - Afrobeats ... mixes Afrobeat with hip-hop and electronic influences as well as Caribbean beats and highlife" (Easter 2019). Afrobeats gained traction in Europe's and North America's urban underground music scene in the late 200os. By 2016, leading artists of the genre were filling some of the biggest music arenas in Europe, North America and the Caribbean. In the 1980s and 199os, African artists like Manu Dibango, Youssou N'Dour, Miriam Makeba, Angélique Kidjo and King Sunny Adé, among others, became famous in world music, selling out big arenas in Europe and North America. Primarily produced for and largely consumed by Western cosmopolitan audiences, world music relied heavily on Anglo-American music executives and their music networks for organizational matters, production, distribution, and marketing (Connell and Gibson 2004). In contrast, Afrobeats is widely popular in the urban music scene across Africa and Afrobeats artists have been able to retain some influence in the production and management of their music (Stassen 2019). Like the African tech innovators above, Afrobeats artists are exclusively young (millennials). The following story of a leading Afrobeat artist highlights the appeal of the genre to a world audience and the artists' commercial success.

Take the case of the 29-year-old Nigerian Afrobeats artist Wizkid who rose from nothing in the mid-2ooos to being one of the scene's biggest names today. In 2008 Wizkid was invited from Nigeria to perform at a 300-capacity nightclub in East London and, after the performance, slept on the event promoter's sofa (Obkircher 2020). Ten years later, in 2018 and 2019, Wizkid performed in and sold out the 20,00о-capacity $\mathrm{O}_{2}$ Arena in London (ввС News 2018). Back in Africa he had sold-out stadium concerts in Sierra Leone, Rwanda, Cameroon, and South Africa (McCarthy 2018). Since 2013 he has collaborated with several renowned artists from different parts of the world. His single 'one dance' with the Canadian rapper Drake was a big success internationally, topping the prestigious US Billboard hot 100 chart for ten consecutive weeks in 2016. The song also became number one in 15 different countries including Canada, the United Kingdom, Australia, Germany, and France (Odusanya 2019). In 2019 Wizkid was one of several Afrobeats singers who collaborated with Beyoncé for the soundtrack of the Disney movie Lion King 2. His hard work has earned him international recognition in the form of profitable business deals and 
prestigious musical awards, both at home and abroad. Among his awards are вEт, Billboard Music Award, iHeart Radio Music Award, mTv Europe Music Awards, Grammy Awards and the MTv Africa Music Award.

The fame enjoyed by Afrobeats artists has translated into lucrative economic deals that are beneficiary to the artists and their communities. Davido (a 27-year-old Nigerian singer) in a recent interview captured the economic and cultural potentials of Afrobeats so succinctly when he stated: "It's [Arobeats] our new oil. When I lived in America, being African wasn't cool. ... Now, people talk about the culture, the food. Now everybody wants to make African music" (Obkircher 2020). In 2017 Wizkid signed a lucrative deal with RCA Records and Sony Music International. The deal has been described as the biggest recording deal given to an African artist (Platon 2017). Moreover, he has enjoyed major endorsement agreements by Pepsi, MTN Nigeria, Guinness, Nike and Dolce \& Gabbana among others (Nigerian Finder n.d.). His agreement with Dolce \& Gabbana saw him walk the runway in Milan with British supermodel Naomi Campbell. Also, Wizkid has established his own clothing line and, partnered with Daily Paper, an Amsterdam based men's African streetwear fashion brand, will work on a limited-edition collection of clothing and accessories.

In 2013, Wizkid launched the Starboy Entertainment label and signed up several young artists from Nigeria and Ghana, including Mr Eazi, a 28-year-old Nigerian who has enjoyed wide success internationally in the past few years. He was one of two African artists to perform at the Coachella Valley Music and Arts Festival (one of the biggest and most profitable music festivals in the USA) in 2019 .

Culturally and politically, Afrobeats' success is a source of pride for many young Africans, and especially so for those of an African background in the diaspora. Echoing Davido's statement above that being African was not cool when he lived in the USA, a young Surinamese-Dutchman said that, "A lot of dark [skin] youth are ashamed of their roots; you see that in how they present themselves: in the past they looked down upon Ghanaians and Nigerians. But now with Afrobeats, Afrodance, Azonto ... everybody feels attracted to Africa" (de Witte 2019: 63). According to London-based radio and TV presenter Olajide, Afrobeats has an identity-strengthening impact because fans see no difference between its artists and US or UK rap artists (Obkircher 2020). Teenagers in Europe frequently see Afrobeats artists collaborating with peers in Europe and North America, and they listen to their music on the same airwaves. In other words, if Afrobeats artists are as popular and cool as European and North American ones, then it is easy to identify with them and their African roots. Furthermore, the young people's embrace of their African identity and 
of Africa as their 'motherland' has political undertones. These are reflected in recent initiatives calling for Africans in the diaspora to return to Africa, as well as in the Black Lives Matter movement across the world, whose black emancipation slogans have entered Afrobeats' lyrics (Burna Boy 2020). Generally, the identification of different audiences with Afrobeats artists valorizes African popular culture on a global scale. Moreover, with their professional success, Afrobeats artists are helping to craft potential pathways for future generations of African artists.

\section{4}

\section{Conclusion}

It was our goal in this chapter to shed light on the agency of African youth, a segment of society largely left out of decision making on vital issues affecting their lives and the broader society. These issues, among others, include the high level of youth unemployment and Africa's perceived abjection. As we have shown, Africa has great potential in innovation and creativity despite significant political and economic hurdles. The drivers of these developments are not the established elites but young, gifted people, often from modest family backgrounds. They stand out because of their entrepreneurial spirit and their willingness to reach out, establish global networks, and form equal partnerships. In this, they differ strongly from conventional development approaches, in which development is construed in terms of financial and technical assistance flowing from the Global North to the Global South, and which generally exclude the targeted populations from designing development programmes and crafting their own solutions (see for example Sachs and McArthur 2005). The case studies presented in this chapter suggest that instead of external assistance, young Africans are showing a preference for joint investment initiatives with business enterprises in the Global North, which allow them to develop their own products and sell them in the local and global markets. With their youthful driving force and networking across cultural and geographical boundaries, they succeed in placing Africa on the global map of technical innovation, in setting global musical trends, and in shaping African futures.

\section{Acknowledgement}

We thank Collins Nji for sharing his story with us. 


\section{References}

African Union. 2006. "African youth charter." African Union, 2 July. https://au.int/en/ treaties/african-youth-charter.

Ashford, L. S. 2007. "Africa's youthful population: Risk or opportunity." Population Reference Bureau. http://www.prb.org/pdfo7/africayouth.pdf.

Atabong, A. B. 2019. "Cameroon's plan for a francophone-led tech hub isn't being welcomed in its anglophone region." Quartz Africa, 23 January. https://qz.com/ africa/1530993/cameroon-plans-francophone-tech-hub-undermines-siliconmountain/.

Ayitey, C. 2017. French President Emmanuel Macron and Dutch Prime Minister Mark Rutte visit impact hub Accra, Garage Development, 2 December. https://gharage. com/2017/12/o2/emmanuel-macron-mark-rutte-visit-impact-hub-accra/ [27 March 2020].

Baah-Boateng, W. 2016. "The youth unemployment challenge in Africa: What are the drivers?" The Economic and Labour Relations Review, 27, 4: 413-431. DoI: 10.1177/1035304616645०3०.

Bayen, M. and D. Giuliani. 2018. "Africa: A look at the 442 active tech hubs of the continent." GSMA, 28 March. https://www.gsma.com/mobilefordevelopment/blog-2/ africa-a-look/.

ввс Africa. 2017. "Google coding champion whose Cameroon hometown is cut off from the Internet." ввс Africa, 10 February. https://www.bbc.com/news/worldafrica-38922819.

ввс News. 2018. "Wizkid sellout im show for O2 Arena." ввс News/Pidgin, 28 May. https://www.bbc.com/pidgin/tori-44277517.

Burna Boy. 2020. "Monsters you made (feat. Chris Martin)." 27 August. https://www. youtube.com/watch?v=lRpBLAwIbeA [17/9/2020].

Connel, J. and C. Gibson. 2004. "World music: Deterritorializing place and Identity." Progress in Human Geography, 28, 3: 342-361.

de Witte, M. 2019. "From bokoe bullying to Afrobeats: Or how being African became cool in black Amsterdam." In Locating African European studies: Interventions, intersections, conversations, edited by F. E. Garrido, C. Kögler, D. Nyangulu and M. Stein, 62-78. New York: Routledge.

Easter, M. 2019. "Mr Eazi and Burna Boy highlight the rise of afrobeats at Coachella." Los Angeles Times, 20 April. https:/www.latimes.com/entertainment/music/ coachella/la-et-ms-coachella-afrobeats-mr-eazi-burna-boy-2019o312-story.html.

Forbes Africa. 2020. "Why big tech is heading to Africa." Forbes Africa, 2 March. https:// www.forbesafrica.com/technology/2020/03/o2/tech-ceos-visit-africa-as-why-ofbig-innovation-and-talent/. 
Hampshire, K, G Porter, S. A. Owusu, S. Mariwah, A. Abane, E. Robson, A. Munthali, A. DeLannoy, A. Bango, N. Gunguluza and J. Milner. 2015. "Informal m-health: How are young people using mobile phones to bridge healthcare gaps in sub-Saharan Africa?" Social Science \& Medicine, 142: 90-99.

Hall, J. 2015. "Mid-2015: A dangerous time for many African leaders." Africa Conflict Monitor, 2015, 6: 4-9.

Human Rights Watch. 2019. Cameroon: Events of 2018. Human Rights Watch. https:// www.hrw.org/world-report/2019/country-chapters/cameroon.

Ibrahim, M. 2018. "Mo Ibrahim slams 'aged African leaders” YouTube video, 7 March. https://www.youtube.com/watch?v=1LvUi6rhTtw.

King, E., S. Santoso and K. Gage. 2014. Making for a stronger Africa. White House blog, 19 August. https://obamawhitehouse.archives.gov/blog/2014/o8/19/makingstronger-africa [22 November 2017].

McCarthy, J. 2018. "Harlem is everywhere." Project Muse, 65, 2: 6-13. DoI: 10.1353/ dss.2018.0022.

Mavhunga, C. C. 2017. "Introduction." In What do science, technology, and innovation mean from Africa?, edited by C. C. Mavhunga, 1-27. Cambridge, MA: MIT Press.

Nadesh, E. 2020. "French business community and ambassador donate generators to Silicon Mountain." ActivSpaces, 18 March, https://www.activspaces.com/blog/ french-donations-to-silicon-mountain/.

Ngwa, E. 2017. "How Silicon Mountain evolved into Cameroon's most vibrant techsphere." Afro Hustler, ${ }_{5}$ November. https://www.afrohustler.com/silicon-mountaincameroons-most-vibrant-techsphere/.

Nigerian Finder. n.d. "Wizkid net worth, assets, endorsement and investments." NigerianFinder.com. https://nigerianfinder.com/wizkid-net-worth/.

Obkircher, F. 2020. "The story behind West Africa's booming musical export," The Red Bulletin, 12 March. https:/www.redbull.com/int-en/theredbulletin/the-storybehind-afrobeats-popularity.

Odusanya, R. 2019. "History of Wizkid's success," Legit. https://www.legit.ng/1175421history-wizkids-success.html [4/9/2020].

Onsongo, E. 2019. "Institutional entrepreneurship and social innovation at the base of the pyramid: The case of M-Pesa in Kenya." Industry and Innovation, 26, 4: 369-39o. DOI: 10.108 o/13662716.2017.1409104.

Platon, A. 2017. "WizKid signs multi-album deal with RCA Records/Sony Music International." Billboard, 1 March. https://www.billboard.com/articles/columns/hip-hop/ 7708975/wizkid-signs-rca-records-sony-music-deal.

Pánek, J., L. Marek, V. Pászto and J. Valuch. 2017. "The crisis map of the Czech Republic: The nationwide deployment of an Ushahidi application for disasters." Disasters, 41, 4: 649-671. DOI: 10.1111/disa.12221. 
Pichai, S. 2017. "So inspired by Nji's story \& look forward to welcoming him and all the winners to the Googleplex." Twitter (@sundarpichai), 2 February, 2:50 a.m. https:// twitter.com/sundarpichai/status/8302325013731328oo.

Radomile, M. 2017. "Announcing the Google Code-in 2016 winners!" Google Open Source Blog, 30 January. https://opensource.googleblog.com/2017/o1/announcinggoogle-code-in-2016-winners.html.

Sachs, J. D. and J. W. McArthur. 2005. "The Millennium Project: A plan for meeting the Millennium Development Goals." Lancet, 365, 9456: 347-353.

Stassen, M. 2019. "Mr Eazi on the global success of afrobeats and his mission to empower the next generation of artists." Music Business Worldwide, 7 October. https://www. musicbusinessworldwide.com/mr-eazi-on-the-global-success-of-afrobeats/.

Undesa (United Nations Department of Economic and Social Affairs). 2019. World population prospects 2019: Highlights (ST/ESA/SER.A/423). https://population. un.org/wpp/Publications/.

UNDP Africa. 2017. "Africa's defining challenge," UNDP Africa, 7 August. https://www. africa.undp.org/content/rba/en/home/blog/2017/8/7/africa_defining_challenge. html.

UNOSSC. 2019. "UNOSSC's Youth 4 South programme joins forces with African Union Commission for the ' 1 Million by 2021 Initiative." The United Nations Office for South-South Cooperation, 24 September. https://www.unsouthsouth .org/2019/og/24/unosscs-youth4south-programme-joins-forces-with-african -union-commission-for-the-1-million-by-2021-initiative/.

Zukane, M. and A. T. Tangang. 2017. "The state of youth policies in the Central African sub region." African Educational Research Journal, 5, 2: 156-169. 